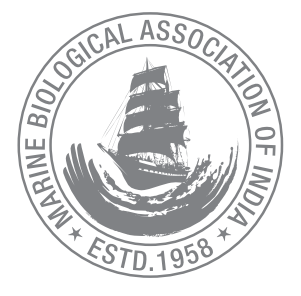

\title{
Growth and maturity of Indian oil sardine Sardinella longiceps (Valenciennes, 1847) along southwest coast of India
}

\author{
Preetha G. Nair*, Shoji Joseph, V. Kripa, R. Remya and V. N. Pillai \\ ICAR-Central Marine Fisheries Research Institute, P. B. No.1603, Kochi-682 018, Kerala, India. \\ *Correspondence e-mail: preethagnair@yahoo.in
}

Received: 10 Feb 2016, Accepted: 25 Jun 2016, Published: 30 Jun 2016

Original Article

\begin{abstract}
Growth studies are important to determine the total recruitment of fish with respect to time while information on age and length at first maturity are essential to assess the spawning stock. The present communication deals with growth, maturity and mortality parameters of Indian oil sardine Sardinella longiceps from southwest coast of India. Length at first maturity of oil sardine was found to be 15.7 and $15.2 \mathrm{~cm}$ for male and female, respectively. Comparison of length at first maturity of oil sardine with earlier studies showed only minor variations. The growth parameters $L_{\infty}, K$, and age at zero length $\left(t_{0}\right)$ were calculated as $19.8 \mathrm{~cm}$, $1.14 \mathrm{yr}^{-1}$ and -0.0464 respectively. From the VBG equation, the length attained at the end of I, II and III year is estimated as 13.79, 17.87 and $18.9 \mathrm{~cm}$ respectively. Two peaks of recruitment to the fishery were observed. The values of total mortality (Z), natural mortality (M) and fishing mortality (F) estimated are 4.33, 2.7 and 1.6 respectively. The exploitation rate was found to be 0.37 .
\end{abstract}

Key words: Oil sardine growth, length infinity, length at first maturity, mortality parameter.

\section{Introduction}

The Indian oil sardine, Sardinella longiceps (Valenciennes) is a small pelagic fish belonging to the family Clupeidae, which contributes to about $40 \%$ of the marine fish catch in Kerala, India. It usually inhabits the pelagic zone confined to at a depth range of 20-200 meters from the coast line. Oil sardine grows rapidly, mature early and a few continue to survive in the subsequent years (Longhurst and Wooster, 1990). They attain sexual maturity when they are $\sim 15 \mathrm{~cm}$ length, at around a year old (Hornell and Nayudu, 1924; Balan, 1964; Raja, 1969; Whitehead, 1985). The life span of oil sardine is $\sim 2.5$ years and they attain a maximum total length of about $23 \mathrm{~cm}$ (Balan, 1964). They play a crucial role in the pelagic ecosystem as a dominant plankton feeder and also forms a major food source (prey) for large predators.

Electronic Length Frequency Analysis (ELEFAN) software used to analyze the growth parameters and to predict fishery yield or stock-related attributes. Annigeri et al. (1992), Abdusamad et al. (2006, 2010); Rao, (1998 a, b) and Nair (1998) have studied the growth rates of sardine, mackerel and anchovy, respectively, using ELEFAN. It is well accepted that the frequent analysis of parameters of growth, mortality 
and maturity is important to understand any fluctuation in population size, structure, and distribution due to longterm environmental change (McRae and Diana, 2005). It is also known that the life history traits of fishes determine the productivity of the fishery resources, which should be integrated with the scientific advisories for fisheries management including the size/age at first maturity, sex ratio, fecundity, spawning periods and spawning behaviour (Katsukawa, 1997; Morgan, 2008).

In this study, attempts have been made to assess growth parameters like, length at infinity $\left(\mathrm{L}_{\infty}\right)$, growth coefficient $(K)$, length at 0 age $\left(t_{0}\right)$, length at age $\left(L_{1}\right)$, recruitment pattern, probability of capture, mortality parameters and size at maturity $\left(L_{m}\right)$ of $S$. longiceps using length frequency data. The values obtained for various parameters in the present study were used to compare the data available from the earlier studies for understanding whether there is any long-term change in these parameters.

\section{Material and methods}

Fortnightly sampling of oil sardine, were carried out from two major fish landing centers (Kalamukku and Munambam) in Kochi, Kerala, west coast of India during the period 2010 -2011. A total of 1395 numbers oil sardine, caught by ring seine and purse seine were used for the present analysis. The total length was taken from the tip of the snout to the tip of the caudal fin using a measuring scale and weight using a weighing balance after wiping off the water on the fishes. Maturity was estimated by the observation of male and female gonads after dissection. Specimens with stage I and II gonad stages were considered as juveniles, while those from III to VI were deemed mature (Bensam, 1964).

\section{Growth parameters}

Growth parameters like $L_{\infty}, K, t_{0}$, life span, length at age $\left(L_{1}\right)$, recruitment pattern and probability of capture were estimated from length frequency data of the species using ELEFAN I module in FiSAT software (Gayanilo and Pauly 1997). Length frequency was taken in $10 \mathrm{~mm}$ class intervals and the data of different classes were used to determine the stock structure and growth.

\section{Mortality parameters}

Total mortality (Z) was calculated by length converted catch curve method (Pauly,1983) and natural morality (M) from the empirical formula given by Pauly (1980) using $28.5^{\circ} \mathrm{C}$ as mean environmental temperature input.

$\log _{10} M=0.0066-0.279 \log _{10} L_{\infty}+0.6543 \log _{10} K+0.4634 \log _{10} T$

Fishing mortality was calculated by subtracting $M$ from $Z$, $\mathrm{F}=\mathrm{Z}-\mathrm{M}$

Exploitation ratio (E) was calculated using the formula $F / Z$

\section{Size/length at first maturity}

In order to estimate the length at first maturity $\left(\mathrm{L}_{\mathrm{m}}\right)$, male and female fishes were grouped separately into $0.5 \mathrm{~cm}$ class interval and the fishes with gonad stage III and above were considered as mature. Lm was calculated by following King's method (2007).

\section{Results}

\section{Growth parameters}

The growth parameters $L_{\infty}, K$, and $t_{0}$ were estimated in FISAT1 as $19.8 \mathrm{~cm}, 1.14 \mathrm{yr}-1$ and -0.0464 and it indicated that the recruitment of oil sardine started in May during 2010 and 2011 (Fig. 1). The maximum life span of oil sardine was estimated to be 2.63 years and growth of the species followed the equation $L_{t}=L_{\infty}\left(1-\exp -(k)\left[t-\left(t_{0}\right)\right]\right)$, which confirms that the species grows faster during the early stages of its life. They attain the length $\left(L_{t}\right) 13.79,17.87$ and $18.9 \mathrm{~cm}$ by the end of 1,2 , and 2.6 years, respectively (Fig. 2). Two peaks of recruitment of juveniles to the fishery was observed: a major peak during July-August and a minor

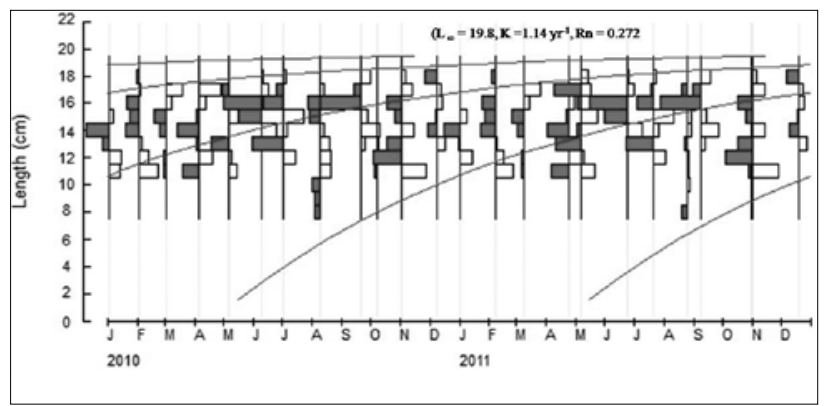

Fig 1. Length-frequency curve of oil sardine (2 years pooled data) using ELEFAN I

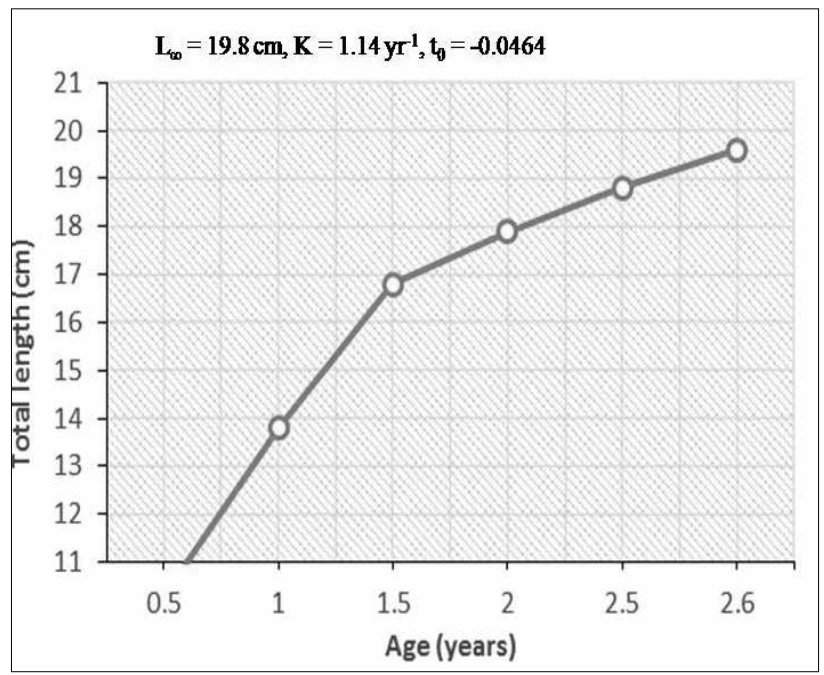

Fig 2. Average length attained by oil sardine at different ages 


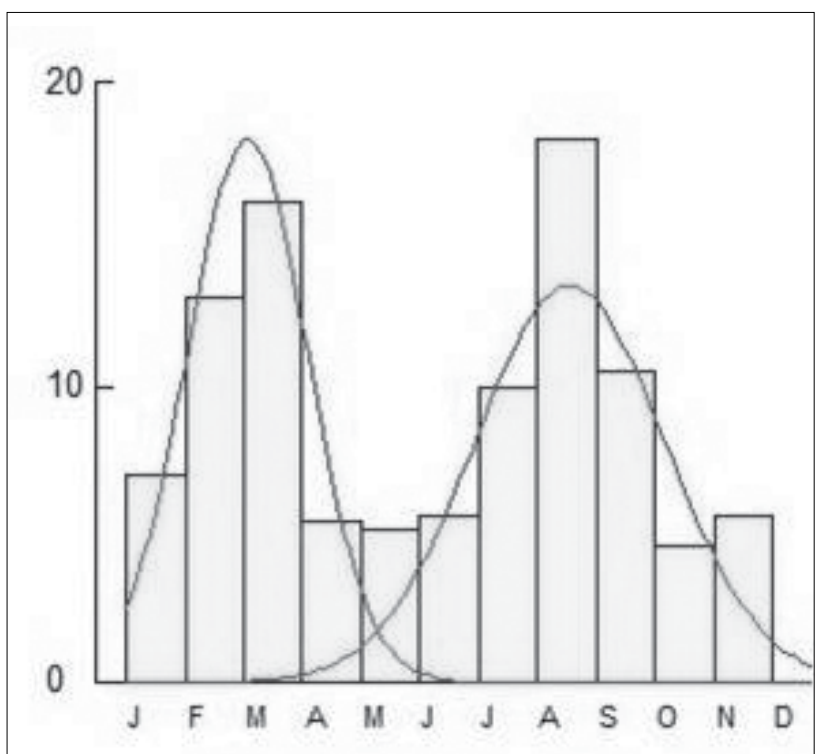

Fig. 3. Annual recruitment pattern of oil sardine based on ELEFAN programme

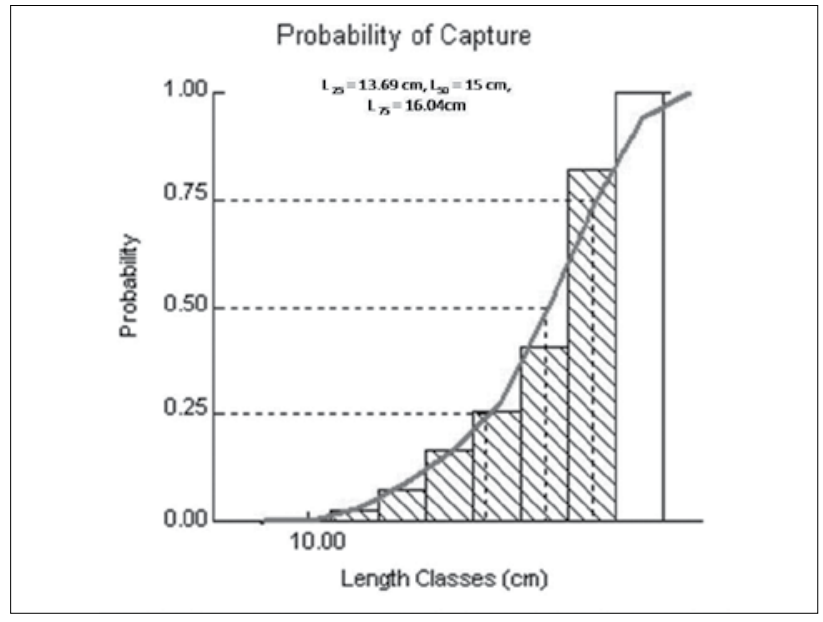

Fig. 4. Probability of capture of oil sardine for $L C_{50}$

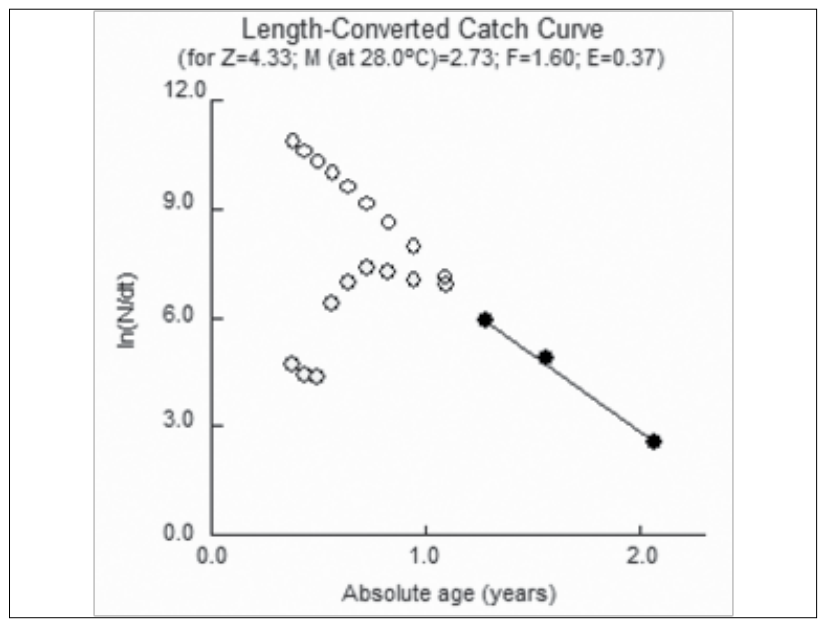

Fig. 5.Length converted catch curve of oil sardine peak during February-March (Fig. 3). The calculated values of probability of capture (Fig. 4) were $\mathrm{L}_{25}=13.69 \mathrm{~cm}, \mathrm{~L}_{50}=$ $15 \mathrm{~cm}$ and $\mathrm{L}_{75}=16.04 \mathrm{~cm}$.

\section{Mortality parameters}

Natural mortality (M) was estimated as $2.7 y^{-1}$ at an annual mean temperature $28.5^{\circ} \mathrm{C}$. The length converted catch curve method gave the total mortality (Z) as $4.33 \mathrm{y}^{-1}$ and from the values of $Z$ and $M$, fishing mortality (F) was estimated as 1.6y-1 (Fig.5). The exploitation ratio observed for $S$. longiceps was 0.37 indicating that this resource was not over exploited.

Size/ length at first maturity $(\mathrm{Lm})$

Length at first maturity of oil sardine was found to be 15.7 and $15.2 \mathrm{~cm}$ for male and female respectively (Fig.6a \& b).

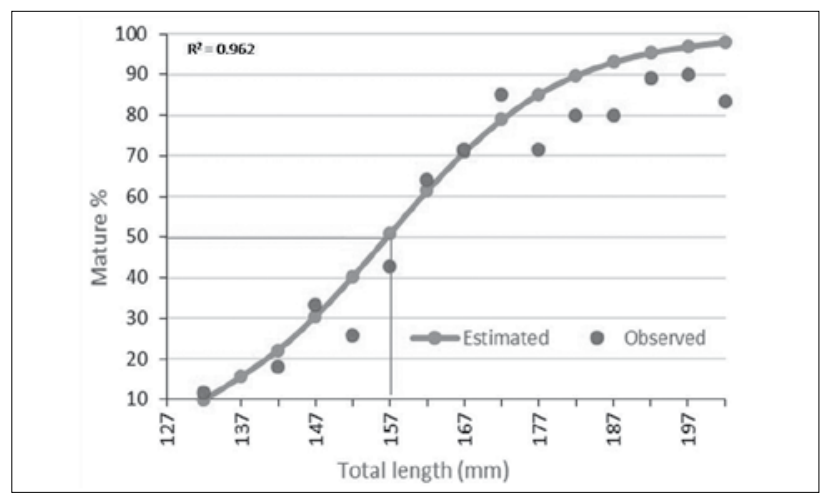

Fig. 6a. Length at first maturity of male oil sardine

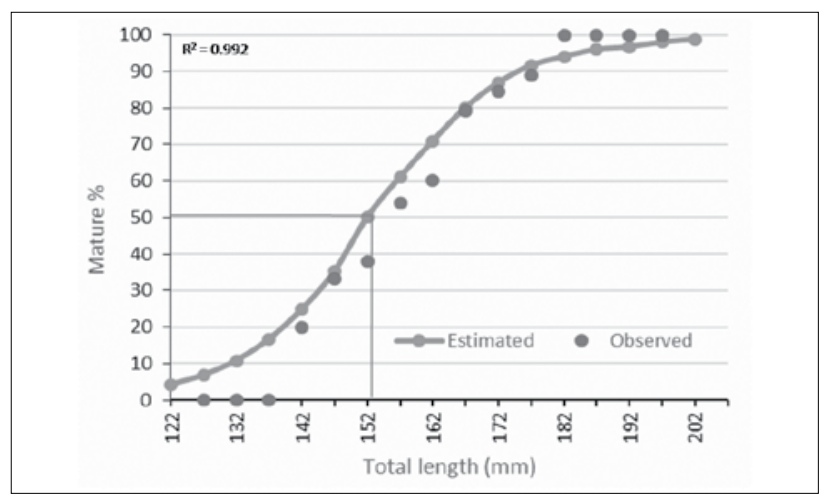

Fig. 6b. Length at first maturity of female oil sardine

\section{Discussion}

The coastal waters of Kerala have high plankton production due to large quantities of nutrients being introduced into the surface waters through large land/river input and upwelling (Madhupratap et al., 1996). Most of the small pelagic fishes in this environment live for only about two years and are exploited at less than one year before they get a chance to reproduce 
even once (Pillai, 2011). The recruitment of juveniles to the stock is thought to be influenced by the annual fluctuations in the intensity and duration of upwelling and plankton bloom in the coastal waters (Pillai, 2011). Pauly (1982) has shown that recruitment even in tropical fishes generally oscillates seasonally and is often normally distributed with one or two peaks per year. This situation influences the availability of different varieties of fish for exploitation. The daily rainfall along the southwest coast during monsoon has been considered useful for good recruitment to the fishery (Pillai 2011). The success of the commercial fishery during each season is determined by the number of juveniles recruited at the beginning of the season, which, in turn, is influenced by several environmental factors such as rainfall and plankton abundance (Pillai, 2011). The present study on the oil sardine from the south west coast of India for the years 2010 and 2011 is after a gap of 10 years when the last study was done by Pillai et al., 2003.

The $L_{\infty}$ and $K$ obtained in the present study are lower than the values of $20.8 \mathrm{~cm}$ and $0.6 \mathrm{yr}^{-1}$ reported by Raja (1972). Similarly, the growth was found to be lower than the values reported by Hornell and Nayudu (1924), who showed a length $15-17 \mathrm{~cm}$ in the first year, $19 \mathrm{~cm}$ in the second year and $23 \mathrm{~cm}$ in the third year. However, the present growth values of oil sardine obtained were higher than the values reported by Nair (1958), who reported a length of 10 $\mathrm{cm}, 15 \mathrm{~cm}$ and $19 \mathrm{~cm}$ in the first, second and third years, respectively. The life span of oil sardine in the present study was found to be 2.6 years, which was comparable with Nair (1958), who reported it as 2.5 years. It was also found in the present study that oil sardine follows a two-year life cycle in their life from recruitment to maturity and attains first maturity at the age of one.

The spawning season of oil sardine has been recorded by several workers as May - August (Hornell and Nayudu, 1924), June - August (Kumaran et al., 1988), June - October (Raja, 1967, 1969), June - September (Dhulkhed, 1967) and June - December (Prabhu and Dhulkhed, 1970). The present study shows two peak recruitment periods, one in February or March and the other from in May - August, which indicates spawning during these months or just before these months. Pillai et al. (2003) reported that oil sardine grows rapidly during the first few months and the length at first maturity is $15 \mathrm{~cm}$, which was slightly lower than the value obtained in the present study $(15.2 \mathrm{~cm}) . L_{c}$ of oil sardine estimated in the present study was $15 \mathrm{~cm}$, which is very close to the length at first maturity. Hence, the results indicate that the oil sardine exploitation start before they attain their first maturity $(\mathrm{Lm}=$ $15.2 \mathrm{~cm}$ ). The maximum size of the exploitated catch in the present study was $16.04 \mathrm{~cm}$ while the corresponding age was
1.5 years. The total life span of oil sardine estimated in the present study was 2.6 years while the corresponding length was $18.8 \mathrm{~cm}$. This indicates that most of the individuals in the stock do not get a chance to grow to their maximum size, getting exploited much before.

The exploitation ratio (E) was found to be 0.37 . According to the present study, the natural mortality was significantly larger than fishing mortality due to the increase of predators such as tuna, kingfishes and other large pelagic fishes or subjected to some oceanographic events. The mortality parameters and exploitation rates from previous studies of $S$. longiceps (Annigeri, 1971; Annigeri et al., 1992) based on the length frequency shows agreements with the present study.

\section{Long-term trends in the length at first maturity}

The length at first maturity of fishes can fluctuate due to changes in the climatic conditions, food availability, fishing removals and growth rates (Hood and Johnson, 2000; Potts and Manooch, 2001). Considering these factors, attempts have been made to analyze the long-term changes in the length/size at first maturity of the oil sardine, for which the present data has been compared with the past data.

Hornell and Nayadu (1924) reported the length at first maturity as $15.0 \mathrm{~cm}$, Dhulkhed (1967) $16.0 \mathrm{~cm}$, Raja (1967) 15.0-16.0 $\mathrm{cm}$ whereas Kumar and Balasubramanian (1987) reported $15.6 \mathrm{~cm}$ for male and $15.8 \mathrm{~cm}$ for female. In the present study, the length at first maturity of oil sardine were $15.7 \mathrm{~cm}$ and $15.2 \mathrm{~cm}$ for male and female respectively, suggesting only minor variations with the past observations.

\section{Acknowledgments}

The authors wish to thank the Director, Central Marine Fisheries Research Institute (CMFRI), Kochi, India, for encouragement, facilities and administrative support and Director, INCOIS, Hyderabad for the financial support. We also thank Dr. K. S. Mohamed and Dr. E. M. Abdusamad, Principal Scientists for their valuable suggestions.

\section{References}

Abdussamad, E. M., M. H. Kasim and P. Acharya. 2006. Fishery and population characteristics of Indian mackerel, Rastrelliger kanagurta (Cuvier) at Kakinada. Indian J. Fish., 53: 77-83.

Abdussamad, E. M., N. G. K. Pillai and M. H. Kasim. 2010. Fishery, biology and population characteristics of the Indian mackerel, Rastrelliger kanagurta (Cuvier) exploited along the Tuticorin coast. Indian J. Fish., 57: 17-21.

Annigeri, G. G. 1971. Estimation of mortality rates of the oil sardine, Sardinella longiceps Val. Indian J. Fish., 18 (1\&2): 109-113.

Annigeri, G. G., K. N. Kurup, M. Kumaran, Mohan Madan, G. Luther, P. N. Nair, Radhakrishnan, Rohit Prathibha, G. M. Kulkarni, J. C. Gnanamuttu, and Rao, K Narayana. 1992. Stock assessment of oil sardine, Sardinella longiceps Val., off west coast of India. Indian J. Fish., 39: 125-135.

Balan, V. 1964. Studies on the age and growth of the oil sardine Sardinella longiceps Val. by means of scales. Ind. J. Fish., 11 A: 663-686.

Balan, V. 1965. The fecundity and sex composition of Sardinella longiceps Val., along the Cochin coast Indian J. Fish., 12 A: 473-491. 
Balan, V. 1971. Fishery and biology of the oil-sardine, Sardinella longiceps Val., off the Cochin coast Indian J. Fish., 18 (1\&2): 135-147.

Bensam, P. 1964. Growth variations in the Indian oil sardine, Sardinella longiceps (Valenciennes). Indian J. Fish., 11: 699-708.

Bensam, P. 1970. On the fluctuations of the oil sardine Fishery at Cannanore During 1961-1964 Indian J. Fish., 17 (1\&2): pp. 132-148.

Chacko, P. I. 1955. Fish statistics of west coast of Madras state for 1931-32 to 194950. Report on Madras Fish Statistics, $1-9$.

Dhulkhed, M. H. 1967. Observation on the spawning behaviours of Indian oil sardine, Sardinella longiceps (Valenciennes) determined by ova diameter studies. Indian J. Fish., 11A: 371-376.

Dhulkhed, M. H. 1968. Sex ratio and maturity stages of the oil sardine, Sardinella longiceps Val., from the Mangalore zone. Indian J. Fish., 15: 116-126.

Gayanilo, Jr. F. E. and D. Pauly. 1997. The FAO-ICLARM Stock Assessment Tools (FiSAT) Reference Manual. FAO Computerized Information Series (Fisheries), 8, Rome, FAO: pp. 262.

Hornell, J. and Nayudu. 1924. A contribution to the life history of the Indian oil sardine with notes on the plankton of the Malabar Coast. Madras Fish. Bull., 17: 129192.

Hood, P. B. and A. K. Johnson. 2000. Age, growth, mortality, and reproduction of red porgy, Pagruspagrus, from the eastern Gulf of Mexico. Fisheries Bulletin, 98: 723 $-735$.

Katsukawa, T. 1997. Points of view introduction of spawning potential: improvement in the threshold management theory. Review in Fish Biol. and Fishe., 7: 285-289.

King, M. 2007. Fishery biology. Assessment and management (second edition). Fishing News Books, Blackwell Science Limited, pp. 352

Kumaran, M., T. M. Yohannan and F. Khan. 1988. Marine Fish Calendar-Calicut. Mar. Fish. Infor. Sew. T\& E Ser., 81: 9 pp

Kumar, K and K. Balasubramanian. 1987. Fishery and biology of oil sardine Sardinella longiceps (Valenciennes) from coastal waters of Parangipettai. CMFRI Bull.in National Symposium on Research and Development in Marine Fisheries I \& II 1987, 44: $42-45$

Longhurst, A. R. and W. S. Wooster 1990. Abundance of oil sardine (Sardinella longiceps) and upwelling on the southwest coast of India. Can J. Fish. Aquat. Sci., 47: 2407-2419.

Madhupratap, M., T. C. Gopalakrishnan, P. Haridas, K. K. C. Nair, P. N. Aravindakshn, G. Padmavati and Shiney Paul. 1996. Lack of seasonal and geographical variation in mesozooplankton biomass in the Arabian Sea and its structure in the mixed layer. Curr. Sci., 71: 863-868

McRae, B. J. and J. S. Diana. 2005. Factors influencing Density of Age - 0 Brown Trout and Brook Trout in the Au Sable River, Michigan. Transa. American Fish. Soci., 134: $132-140$.

Morgan, M. J. 2008. Integrating reproductive biology into scientific advice for fisheries management J. Northwest Atl. Fish. Sci., 41: 37-51.

Nair, R. V. 1958. The sardines In: Jones. S. (Ed.) Fisheries of the west coast of India, CMFRI, Kochi, p. 31-37.
Nair, R. V. 1959. Notes on the spawning habits an early life history of the oil sardine, Sardinella longiceps Cuv \& Val. Indian J. Fish., 6: 342-359.

Nair, S. 1998. The fishery biology and population dynamics of anchovies of the Kerala coast. Ph.D Thesis, Mahatma Gandhi University, Kottayam, Kerala, India, 210 pp.

Pauly, D.1980.A selection of simple methods for the assessment of tropical fish stocks. FAO Fish. Circ. No.729, 54pp. Issued also in French. Superseded by FAO Fish. Tech. Pap., (234).

Pauly, D. 1982. Studying single-species dynamics in a tropical multi-species context, In Theory and management of tropical fisheries, Pauly D., Murphy G.l., (eds.), ICLARM Conf. Proce., 9: 33-70.

Pauly, D. 1983. Length converted catch curves. A powerful tool for fisheries research in the tropics (Part 1) ICLARM Fish byte, 1: pp. 325.

Pillai N.G.K. 2011. Handbook of fisheries and aquaculture, Indian Council of Agricultural Research, New Delhi, 66-89 pp.

Pillai N.G.K. 2011. Handbook of fisheries and aquaculture, Indian Council of Agricultural Research, New Delhi, 1116 pp.

Pillai, N. G. K., U. Ganga and A. A. Jayaprakash. 2003. Indian Oil Sardine. In: Mohan Joseph and Jayaprakash, (Eds.) Status of Exploited Marine Fishery Resources of India. CMFRI, Cochin, p. 18-24.

Potts, J. C. and C. S. Manooch. 2001. Differences in the age and growth of white grunt from North Carolina and South Carolina versus southern Florida. Bull. Mar. Sci., $68: 1-12$

Prabhu, M. S. and M. H. Dhulkhed. 1970. The oil sardine fishery in the Mangalore zone during the seasons 1963-64 and 1967-68. Indian J. Fish., 17: 57-75.

Raja, A. B. T. 1967. Length-weight relationship in the oil-sardine, Sardinella longiceps Val. Indian J. Fish., 14: 159-170.

Raja, A. B. T. 1969. The Indian Oil Sardine. Bull. Cent Mar Fish Res Inst, Kochi, India, 16: $1-128$.

Raja, A. B. T. 1970. Estimation of age and growth of the Indian oil sardine, Sardinella longiceps Val. Indian J. Fish., 17: 26-42.

Raja, A. B. T. 1 971.Fecundity fluctuations in the oil-sardine, Sardinella longiceps Val. Indian J. Fish, $18: 84-98$.

Raja, A. B. T. 1972. Estimation of age and growth of the Indian oil sardine Sardinella longiceps. Val. Indian J. Fish., 17: 26-42.

Rao, S. G. 1988a. Biology of Stolephorus devisi (Whitley) from Mangalore area Dakshina Kannada. J. Mar. Biol. Ass. India, 30: 28-36.

Rao, S. G. 1988 b. Some aspects of biology of Stolephorus bataviensis Hardenberg, from Mangalore area, Dakshina Kannada. J. Mar. Biol. Ass. India, 30: 107-113.

Whitehead, P. J. P.1985. FAO species catalogue, Volume 7, Clupeid fishes of the world (suborder Clupeoidei). An annotated and illustrated catalogue of herrings, sardines, pilchards, sprats, anchovies and wolf herrings. Part 1 - Chirocentridae Clupidae and Pristigasteridae.FAO Fish. Syn., 7, part 1: pp. 303. 